\title{
Mitral Valve Replacement in Children and Adolescents with Rheumatic Heart Disease
}

\author{
Stanley John, M.S., M.S., (Thor.), F.A.C.C., \\ Susil Munsi, M.R.C.P., I. P. Sukumar, F.R.C.P., D.M., \\ and George Cherian, M.D., D.M.
}

\section{Summary}

To our knowledge, no documented hemodynamic studies in larger series of young patients undergoing valve replacement for rheumatic valvular disease have been reported previously. It seems to us that the natural history of rheumatic heart disease in India often follows a rapid and fulminant course which makes an aggressive surgical approach mandatory.

An operative mortality of $22 \%$ was seen in this series. Pronounced cardiac disability together with the poor general condition and the low nutritional status contributed in no small measure to this figure. Patients have been followed for periods ranging from 6 months to 6 years following corrective surgery.

A remarkable absence of thrombo-embolic phenomena was a striking feature in the follow-up. There has been no evidence of rheumatic reactivation in any of these patients.

This communication reinforces the beneficial results of valve replacement even at this young age when severe mitral incompetence exists refractory to medical treatment.

\section{Additional Indexing Words:}

Mitral valve replacement Functional class Severe pulmonary hypertension Operative mortality Thromboembolism Prosthesis

7 HE dependability of presently available prosthetic valves offer relief to 1 many patients with serious valvular heart disease. Nevertheless, the role of valve replacement surgery in the management of valvular disease during the first 2 decades of life is not well documented. Reports of valve replacement in children and adolescents are uncommon. The purpose of this communication is to review our experience with 31 young patients with rheumatic heart disease for whom mitral valve replacement was utilized.

From the Departments of Cardiothoracic Surgery and Cardiology, Christian Medical College Hospital, Vellore, India.

Reprint request to: Dr. Stanley John, Thoracic \& Cardiovascular Surgery Dept., C.M.C. Hospital, Vellore-632004, India.

Received for publication October 11, 1975. 


\section{Material and Methods}

Between August 1967 to May 1973, 120 patients underwent replacement of the mitral valve in the Department of Cardiothoracic Surgery at the Christian Medical College Hospital, Vellore in South India. Of these, there were 31 young patients whose ages ranged from 12 to 20 years at the time of operation. None was judged to have clinical or laboratory evidence of recent rheumatic activity. Of the 31,16 were males and 15 were females and their weights ranged from 19 to $54 \mathrm{Kg}$ (Table I).

Table I

\begin{tabular}{|c|c|c|c|c|c|}
\hline \multirow{2}{*}{\multicolumn{2}{|c|}{ Age (Years) }} & \multicolumn{2}{|c|}{ Weight $(\mathrm{Kg})$} & \multicolumn{2}{|c|}{ Body Surface Area $\left(\mathrm{M}^{2}\right)$} \\
\hline & & Male & Female & Male & Female \\
\hline \multirow[t]{3}{*}{$10-15$} & Number & (4) & (4) & $(4)$ & (4) \\
\hline & Mean & 33.1 & 26.0 & 1.23 & 1.00 \\
\hline & Range & $23-48$ & $19-35$ & $0.91-1.60$ & $0.82-1.28$ \\
\hline \multirow[t]{3}{*}{$16-20$} & Number & (12) & (11) & $(12)$ & (11) \\
\hline & Mean & 41.7 & 38.7 & 1.36 & 1.29 \\
\hline & Range & $27-54$ & $27-54$ & $1.20-1.52$ & $0.82-1.48$ \\
\hline
\end{tabular}

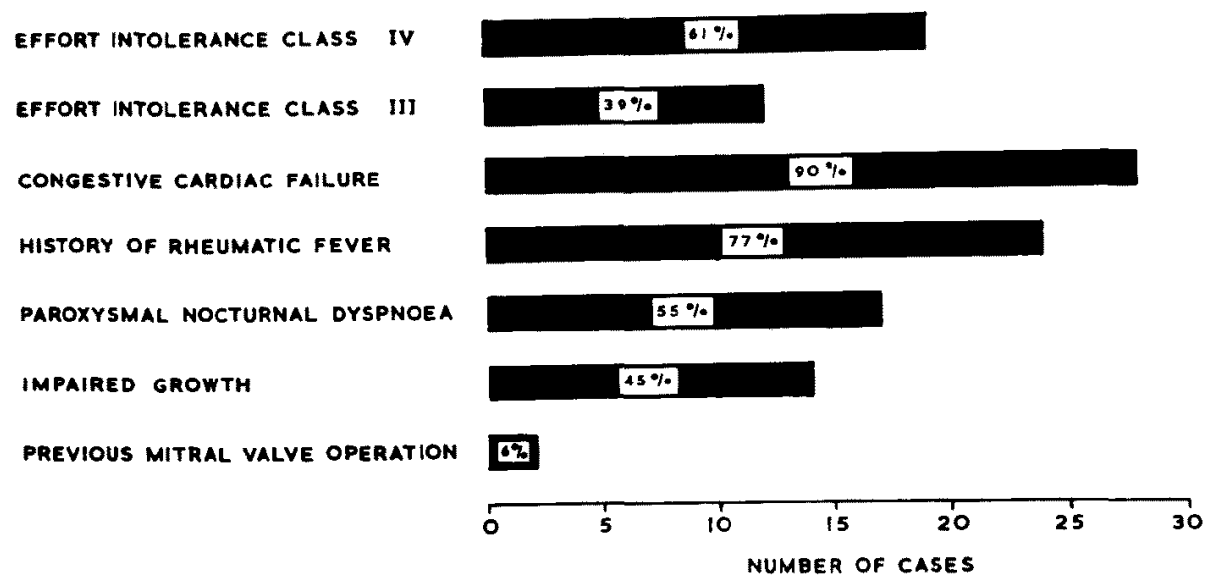

Fig. 1. Preoperative manifestations (31 cases).

Table II. Radiographic Evaluation

\begin{tabular}{c|c|c}
\hline Cardiothoracic Ratio & Grades & No. of Patients \\
\hline $1+55-60 \%$ & 1 & 4 \\
$2+60-65 \%$ & 2 & 6 \\
$3+65-70 \%$ & 3 & 13 \\
$4+>70 \%$ & 4 & 8
\end{tabular}


Sixty-one per cent were in functional class IV and $39 \%$ in functional class III of the New York Heart Association classification.1) Congestive cardiac failure occurred in $90 \%$. Evidence of impaired growth was present in $45 \%$. A history suggestive of rheumatic fever was obtained in $77 \%$ of our patients. One patient has had a previous mitral valve operation (Fig. 1).

Roentgenological features (Table II):

Marked cardiomegaly was present in the majority of patients. The cardiothoracic ratio was over $70 \%$ in 8 patients and between 60 to $70 \%$ in 19 patients. It was between 55 to $60 \%$ in the remainder.

Electrocardiographic findings (Fig. 2):

Of the 31 patients, 14 were in atrial fibrillation while the rest were in normal sinus rhythm. Left atrial hypertrophy was present in 21 cases $(65 \%)$ whilst right ventricular hypertrophy was evident in 18 cases $(61 \%)$. Fifty-eight per cent of the cases showed left ventricular hypertrophy.

Cardiac catheterisation data (Table III):

Cardiac catheterisation and cine angiocardiography were carried out in all except one. Fourteen patients showed evidence of severe pulmonary hypertension. The systemic arterio-venous oxygen difference was over 7 vol \% in 16 patients. Of the 31 patients 7 had evidence of a left to right shunt and of these, 6 were at the atrial level while 1 was a left ventricular-right atrial shunt. Retrograde aortography demonstrated a mild degree of aortic incompetence in 2 cases.

Surgery was accomplished utilizing cardiopulmonary bypass. This was in-

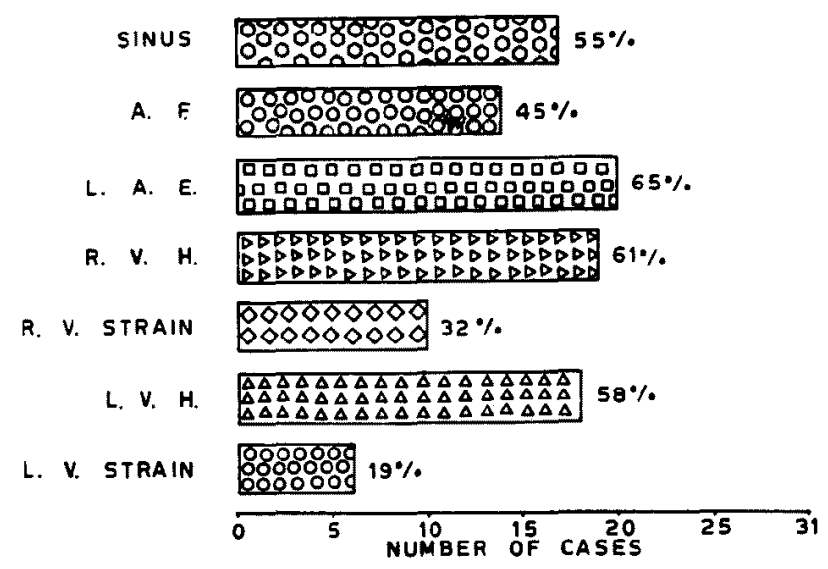

Fig. 2. Electrocardiographic findings ( 31 cases).

Table III

\begin{tabular}{l|c|c}
\hline & Median & Range \\
\hline PA Systolic Pressure (mmHg) & 58 & $27-140$ \\
PA Mean Pressure (mmHg) & 40 & $16-100$ \\
PW Mean Pressure (mmHg) & 20 & $2-40$
\end{tabular}

No. of Cases 30 
stituted using a disc oxygenator with $50 \%$ hemodilution using Ringer lactate and low molecular weight dextran as the diluents. Electrical fibrillation was induced in all cases. Tricuspid valve was routinely explored before linking the patient to the heart-lung machine. A moderate to severe degree of tricuspid incompetence was present in 10 cases. At surgery, the mitral valve was found to be grossly incompetent in 29 and predominantly stenotic in the other 2 cases (Table IV).

Replacement was accomplished using a Starr-Edwards ball valve prosthesis in 28 cases. In 2 cases, a mounted heterograft was used while in 1 a frame-supported autologous fascia lata valve was utilised. Concomitant closure of a large atrial septal defect was accomplished utilising a patch in 6 cases. In 1 with a left ventricular-right atrial shunt, direct suture was employed. In 7 cases, tricuspid annuloplasty was carried out.

Valve prostheses used (Table V):

In this series of 31 patients adult sized valves were employed in all but 2 cases. As shown in this table, the $2 \mathrm{M}$ was the commonest prostheses used while $1 \mathrm{M}$ was used in 8 instances. In only 5 cases, a $3 \mathrm{M}$ prosthesis could be inserted. Postoperatively assisted ventilation through the endotracheal tube was employed in all patients for at least 24 hours. In 4 patients, a tracheostomy was required to continue intermittent positive pressure ventilation for a longer period of time.

Table IV. Findings at Surgery

\begin{tabular}{|c|c|c|c|c|c|c|}
\hline & \multirow{2}{*}{$\begin{array}{c}\text { Grossly } \\
\text { Incompetent } \\
\text { Mitral Valve }\end{array}$} & \multirow{2}{*}{$\begin{array}{c}\text { Predominantly } \\
\text { Stenotic } \\
\text { Mitral Valve }\end{array}$} & \multicolumn{2}{|c|}{$\begin{array}{l}\text { Associated Valve } \\
\text { Involvement }\end{array}$} & \multicolumn{2}{|c|}{ Associated Lesions } \\
\hline & & & $\begin{array}{l}\text { Aortic } \\
\text { Incom- } \\
\text { petence }\end{array}$ & $\begin{array}{l}\text { Tricuspid } \\
\text { Incom- } \\
\text { petence }\end{array}$ & ASD & $\begin{array}{c}\text { LV-RA } \\
\text { Shunt }\end{array}$ \\
\hline No. of Cases & 29 & 2 & 4 & 10 & 6 & 1 \\
\hline Type of Surgery & MVR & MVR & - & $\begin{array}{c}7 \\
\text { (Annulo- } \\
\text { plasty } \\
\text { Done) }\end{array}$ & $\begin{array}{l}\text { Patch } \\
\text { Closure }\end{array}$ & $\begin{array}{l}\text { Direct } \\
\text { Suture }\end{array}$ \\
\hline
\end{tabular}

Table V. Starr Valve Prosthesis Used

\begin{tabular}{|c|c|c|c|c|}
\hline \multirow{3}{*}{ Size } & \multicolumn{4}{|c|}{ Model Number } \\
\hline & \multicolumn{2}{|c|}{ Uncovered Prosthesis } & \multicolumn{2}{|c|}{ Fabric Covered Prosthesis } \\
\hline & 6000 & 6120 & 6300 & 6310 \\
\hline & \multicolumn{4}{|c|}{ Number of Cases } \\
\hline 0 & $\begin{array}{c}2 \\
(1.53)\end{array}$ & - & - & 一 \\
\hline 1 & $\begin{array}{c}1 \\
(2.14)\end{array}$ & $\begin{array}{c}2 \\
(2.14)\end{array}$ & $(2.00)$ & $(2.00)$ \\
\hline 2 & $\begin{array}{c}1 \\
(2.50)\end{array}$ & 一 & $\begin{array}{c}10 \\
(2.20)\end{array}$ & $\begin{array}{c}3 \\
(2.20-2.27)\end{array}$ \\
\hline 3 & $(2.85)$ & $(2.85)$ & $\begin{array}{c}1 \\
(2.62)\end{array}$ & - \\
\hline
\end{tabular}




\section{RESULTS}

I. Mortality data

There was 1 operative death. In addition, 6 patients died during the early postoperative period resulting in a hospital mortality of $22 \%$ (Table VI).

The operative death occurred in a profoundly disabled boy, 19 years of age, on whom a mounted heterograft was used. He had had a previous valvotomy elsewhere and complicating mitral insufficiency. Pulmonary artery pressure was at systemic level. Attempts to terminate cardiopulmonary bypass proved futile in him. Of the postoperative deaths, 1 occurred in a young boy and this was the result of ventricular tachyarrhythmia 6 days following corrective operation. The young girl with severe mitral incompetence and left ventricular-right atrial shunt died from a refractory arrhythmia on the sixth postoperative day. Another patient who was in Class IV ( $\mathrm{N} \mathrm{Y} \mathrm{H} \mathrm{A)} \mathrm{with} \mathrm{severe} \mathrm{pulmonary} \mathrm{hypertension} \mathrm{had} \mathrm{a} \mathrm{sudden} \mathrm{cardiac}$ arrest on the fourth postoperative day. Massive hemothorax related to anticoagulant treatment was the cause of death in another young girl. An-

Table VI. Mortality Data

\begin{tabular}{|c|c|c|c|c|}
\hline Patient & $\begin{array}{c}\text { Age } \\
\text { (Years) }\end{array}$ & $\begin{array}{l}\text { NYHA } \\
\text { Class }\end{array}$ & $\begin{array}{l}\text { Operative } \\
\text { Procedure }\end{array}$ & Causes of Death \\
\hline $\mathrm{K}$ & 17 & IV & MVR & Post Bypass Low Cardiac Output \\
\hline$S \mathrm{~N}$ & 18 & IV & MVR & Ventricular Tachyarrhythmia \\
\hline S K & 18 & IV & $\begin{array}{l}\text { LVRA Shunt } \\
\text { Closure \& MVR }\end{array}$ & Block Refractory Arrhythmia \\
\hline $\mathrm{V}$ & 17 & IV & $\begin{array}{l}\text { MVR + Tricuspid } \\
\text { Annuloplasty }\end{array}$ & $\begin{array}{l}\text { Sudden Cardiac Arrest-4th Post- } \\
\text { op. Day }\end{array}$ \\
\hline $\mathbf{K}$ & 20 & IV & MVR & Bleeding -5 th Postop. Day \\
\hline A & 18 & IV & $\begin{array}{l}\text { MVP+ASD Clo- } \\
\text { sure }\end{array}$ & Low Cardiac Output Syndrome \\
\hline $\mathbf{N}$ & 15 & IV & MVR & $\begin{array}{l}\text { Low Cardiac Output Syndrome } \\
\text { and Fatal Bronchopneumonia }\end{array}$ \\
\hline
\end{tabular}

Table VII. Non-fatal Complications

\begin{tabular}{l|c}
\hline \multicolumn{1}{|c|}{ Nature of Complications } & No. of Patients \\
\hline Cardiac Arrhythmias & 6 \\
Low Cardiac Output & 3 \\
Pulmonary Complications & 6 \\
Post-Pericardiotomy Syndrome & 2 \\
Regurgitant Fascial Graft & 1 \\
\hline
\end{tabular}


other patient, 18 years of age, who was in unrelenting cardiac failure preoperatively died from low cardiac output syndrome on the third postoperative day. Necropsy showed fragmentation of left ventricular endocardium by the rigid cage. A young girl, 12 years of age, with severe pulmonary hypertension died from fulminant bronchopneumonia 3 weeks after surgery.

II. Non-fatal complications (Table VII)

Non-fatal complications included arrhythmias in 6, pulmonary complications in 6 and postpericardiotomy syndrome in 2 cases. A young girl who had an autologous fascia lata valve inserted developed severe mitral regurgitation. Seven weeks following initial surgery she went into a hypotensive state and required emergency cardiopulmonary bypass and valve replacement. The frame mounted fascial graft was removed and a No. 1M Starr prosthesis was inserted. She has done very well since that time and is now leading a normal life.

III. Late death and follow-up (Fig. 3)

Twenty-four patients left the hospital in an excellent condition. There was only 1 late death which occurred in a young girl with a Lutembacher syndrome who died 6 months after surgery. Death was the result of cerebral hemorrhage from anticoagulant treatment. The remaining 23 patients are on anticoagulant treatment attending centres scattered throughout the country in some of which adequate facilities for anticoagulant control are not available. This is a very pertinent problem in this country. Nevertheless, thrombo-embolic phenomena have not occurred in any of our patients.

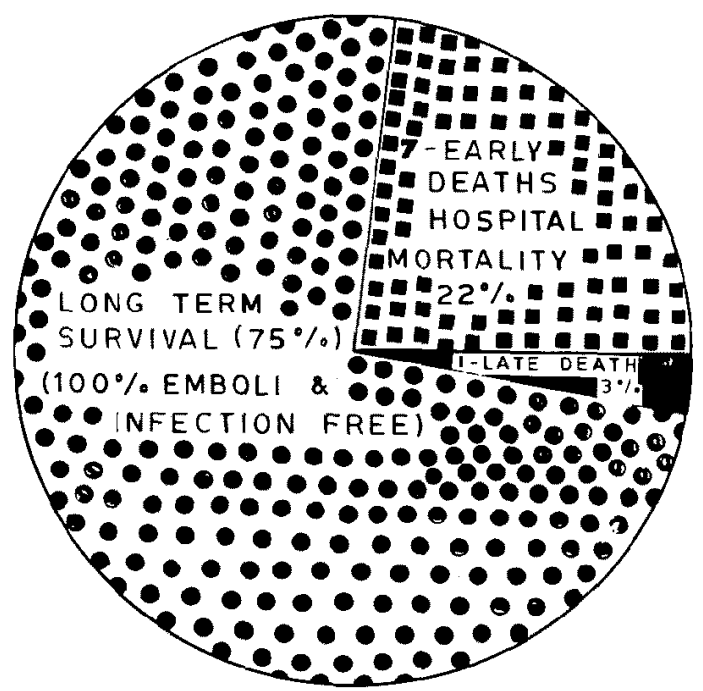

Fig. 3 
Nine of these patients have undergone recatheterisation and the pulmonary artery pressure has shown striking reduction in all except 1 . This study was done 8 months following surgery and it is reasonable to assume that further reduction of pulmonary artery pressure would occur over a period of time. The systemic a-v oxygen difference has shown a very pronounced improvement in all patients indicating satisfactory improvement in cardiac output (Fig. 4). In our follow-up, most gratifying was the observation that 9 subjects who were initially in class IV are now in class I or class 0 (Table VIII). All the 23 patients have had an excellent result during the period of follow-up. Radiographic evaluation demonstrated that 15 cases showed very pronounced reduc-
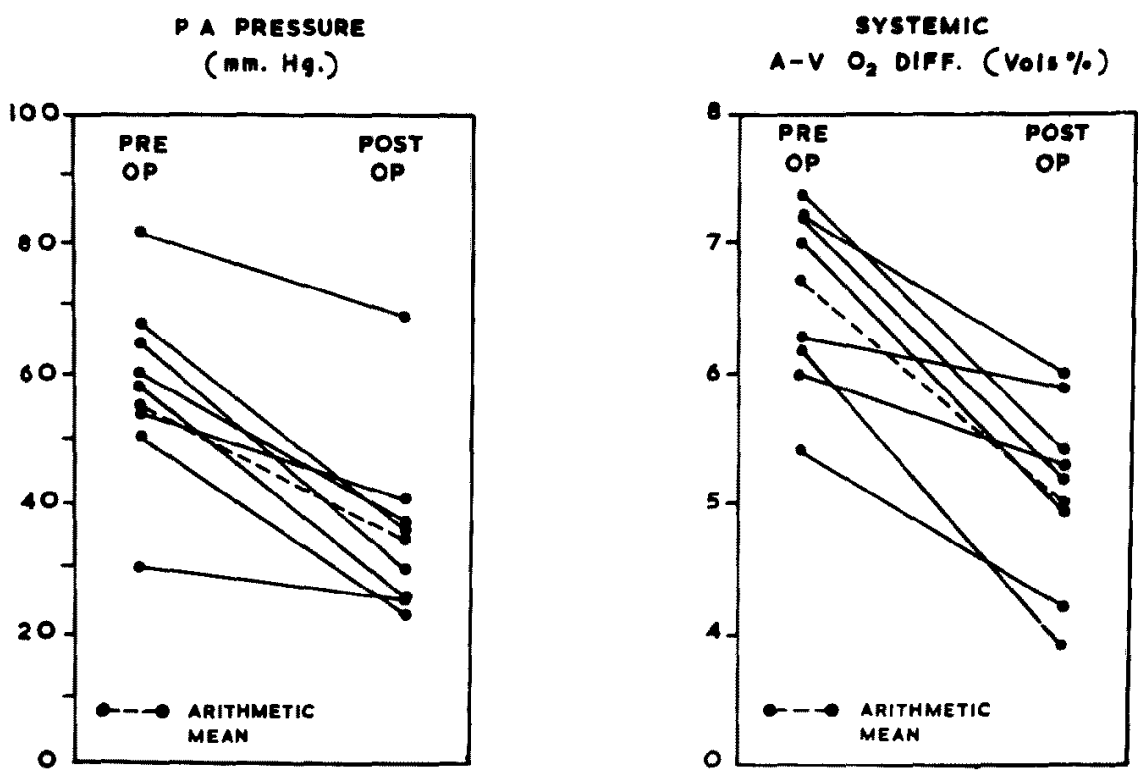

Fig. 4. Pre- and postoperative hemodynamic data.

Table VIII. Results-Improvement in Symptoms (Period of Follow-up: 6/12-6 years)

\begin{tabular}{|c|c|c|c|c|c|c|}
\hline \multicolumn{2}{|c|}{ Preoperative } & \multicolumn{5}{|c|}{ Postoperative Grade } \\
\hline Grades & No. of Cases & 0 & I & II & III & IV \\
\hline & & \multicolumn{5}{|c|}{ (Number of Cases) } \\
\hline 0 & 一 & - & - & - & - & 一 \\
\hline I & - & - & - & - & 一 & 一 \\
\hline II & 一 & - & - & 一 & - & 一 \\
\hline III & 14 & 12 & 2 & 一 & - & - \\
\hline IV & 9 & 3 & 6 & - & - & - \\
\hline
\end{tabular}


tion in the size of cardiac silhouette while in 8 cases, there was only moderate reduction (Fig. 5).

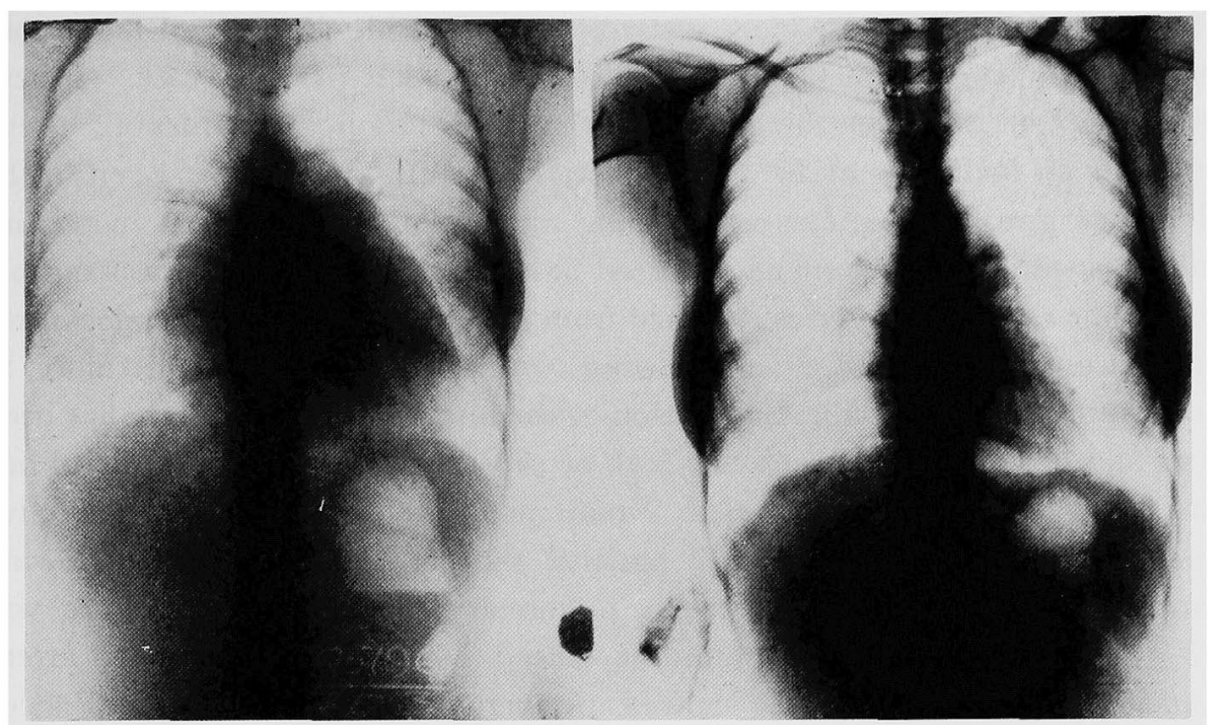

Fig. 5.

\section{Discussion}

Reports of valve replacement in children and adolescents are uncommon. ${ }^{2}$ We have been encouraged to offer prosthetic replacement in young patients where terminal cardiac decompensation exists. The principal deterrent, however, continues to be the rather uncertain future of these valve prostheses. These young patients in our series were between 12 and 20 years of age although history suggestive of rheumatic fever was obtained in $77 \%$ of our patients. Nevertheless, the valves excised at surgery showed scarring, puckering and distorsion very typical of rheumatic valvulitis. Moreover, in a larger series of well documented cases of rheumatic heart disease that underwent surgery reported earlier from this institution, a history of rheumatic fever was obtained only in $53 \%{ }^{3}{ }^{3)}$ Of the 31 patients, 7 had associated shunts either at the atrial or ventricular level. The frequent association of atrial septal defect with rheumatic heart disease is an important haemodynamic entity to remember. ${ }^{4)}$ Seven patients died in the early postoperative period constituting a hospital mortality of $22 \%$. The serious cardiac disability together with a low nutritional status and poor general condition of these patients contributed greatly to this mortality. All these patients who died 
were in functional class IV and the cardiothoracic ratio was $65 \%$ or more in each instance.

There was only 1 late death related to anticoagulant treatment. Our patients have to attend widely scattered centres with the type of laboratory control and supervision being decidedly not the best in every case. A very striking feature has been the absence of thrombo-embolic phenomenon. Levy reported an incidence of $20 \%$ in his series of young patients. ${ }^{5)}$ Even in the older age group of patients undergoing mitral valve replacement in our institution, embolic phenomena occurred only in $4 \%{ }^{6}{ }^{6}$ This contrasts sharply with some of the other series reported from the West." Bacterial endocarditis has not occurred in our series following corrective surgery. Furthermore, in no instance was there any reactivation of rheumatic activity. There has been a virtual absence of paravalvular leak or prosthetic dehiscence in any of our cases. Cardiac catheterisation in 9 patients showed gratifying postoperative hemodynamic results. In the 8 patients that underwent studies following surgery, the average resting mean pulmonary artery wedge pressure was $12 \pm 4 \mathrm{mmHg}$. In no patient did it exceed $18 \mathrm{mmHg}$. Pulmonary artery wedge pressure after exercise showed an average of $17 \pm 5 \mathrm{mmHg}$. Glancey et $a^{81}$ recorded a higher left atrial pressure at rest with the smaller prosthesis size 2 and $3 \mathrm{M}$ in adults. And furthermore, during exercise we found that the mean left atrial pressure was markedly elevated in every patient averaging $25 \mathrm{mmHg}$. Lee et $\mathrm{al}^{9}$ ) with the $2 \mathrm{M}$ and $3 \mathrm{M}$ sizes also in adult patients showed that the pulmonary artery wedge pressurc remained abnormally high at rest $(15 \pm 5 \mathrm{mmHg})(28 \pm 8 \mathrm{mmHg})$. Functional capacity and exercise tolerance have been excellent in the 14 long-term survivors, all of whom are leading active lives. ${ }^{101}$

We would like to express our grateful thanks to the Edwards Laboratories for the generous gift of Starr valve prostheses.

\section{REFERENCES}

1. The Griteria Committee of the New York Heart Association: Diseases of the Heart and Blood Vessels. Nomenclature and Criteria for Diagnosis. ed 6, Little Brown \& Co, Boston, p 112, 1964

2. Joseph M, De Water V, Wolfe RR, Mulder DG: Total heart-valve replacement in the pediatric age group. J Thorac Cardiovase Surg 53: 515, 1967

3. Cherian G, Vythilingam KI, Sukumar IP, Gopinath N: Mitral valvotomy in young patients. Brit Heart J 26: 157, 1964

4. John S, Munsi SC, Bhait BS, Gupta RP, Sukumar IP, Cherian G: Co-existent mitral valve disease with left-to-right shunt at the atrial level. J Thorac Cardiovasc Surg 60: 174, 1970

5. Vidne $B$, Levy MJ: Heart valve replacement in children. Thorax 25: 57, 1970

6. McArthur JD, John S, Joseph TM et al: Mitral valve replacement. Clinical follow-up in twenty-two cases with a haemodynamic study. J Ass Physicians India 18: 889, 1970 
7. Akbarian M, Austen WG, Yurchak PM, Scannel JG: Thromboembolic complications of prosthetic cardiac valves. Circulation 37826,1968

8. Glancey DL, O'Brien MP, Reis RL, Epstein SE, Morrow AG: Hemodynamic studies in patients with $2 \mathrm{M}$ and $3 \mathrm{M}$ Starr-Edwards prostheses. Evidence of obstruction to left atrial emptying. Circulation 39 (Suppl I): 113, 1969

9. Lee SJK, Zaragoza AJ, Callaghan JC, Rossall RE, Frazer RS: Hemodynamic changes following mitral valve replacement with the Starr-Edwards and Cutter-Smeloff prostheses. J Thorac Cardiovasc Surg 61: 688, 1971

10. Bloodwell RD, Hallman GL, Cooley DA: Cardiac valve replacement in children. Surgery 63: 77,1968 